\title{
DEVELOPMENT OF A SUITABLE PLANTER FOR HYBRID RICE CROP
}

Abo-Habaga M. M. ${ }^{1}$; A. E.Abo-Elmagd ${ }^{1}$;M.A.El-Sadany ${ }^{1}$;M.I. Egela ${ }^{2}$ and M.I. El-Meadawy ${ }^{2}$

1- Agric. Eng. Dept., Fac. of Agric. Mansoura Univ., Egypt.

2- Agric. Eng. Res. Inst., El-Dokki, Giza, Egypt.

\begin{abstract}
Laboratory experiment was carried out at Rice Mechanization Center (Agric. Eng. Res. Institute, Ministry of Agric.) in Kafr El-Sheikh to determined some of physical and engineering properties for Egyptian hybrid rice No.1 that help in develope of a suitable precision vacuum planter for sowing dry, soaking and incubated hybrid rice seeds.

The rice seed (dry, soaked and incubated) properties were seed moisture content (Mc), mean dimensions \{Length (L), Width (W) and Thickness (Th)\}, shape index (Si), seed density ( $\rho)$, weight of 1000 seeds (Wi), sphericity (Sp), arithmetic mean diameter $(\mathrm{Da})$, geometric mean diameter $(\mathrm{Dg})$, repose angle (Ra), dynamic coefficient of friction (Fd) and terminal velocity (Tv).

From laboratory experiments, it has been manufacturing a precision vacuum planter unit suitable for planting hybrid rice seeds in two rows with $150 \mathrm{~mm}$ and 150 $\mathrm{mm}$ spaced in the row.
\end{abstract}

\section{INTRODUCTION}

Rice considered one of the most important cereal crop in Egypt. The cultivated area of rice crop was about 1.427 million feddans in year 2012, that produced about 5.66 million ton paddy rice (Bulletin of the Ministry of Agriculture, Agricultural Economy in, 2012). The main objectives of the National Rice Research Institute program is to develop a new varieties of high-yield. Egyptian hybrid rice No.1 is one of this varieties, which it's productivity reached about 5.5 to 6.5 tons / fed and sowing rate about 7.5 to $10 \mathrm{~kg}$ seeds/fed. with a 1-2 plans in the hill and transplanting distances $15 \mathrm{x}$ $15 \mathrm{~cm}$ or $20 \times 20 \mathrm{~cm}$. Ibrahim et al. (2008) studied some physical properties of rice seeds before and after soaking procedures, they found that the values of shape index (SI), actual seeds density $(\rho)$ and mass of 1000 seeds were obtained about 2.81, $99.96 \mathrm{~g} / \mathrm{cm}^{3}$ and $33.03 \mathrm{~g}$ for dry rice seeds (Giza 178) at $12.6 \%$ seed moisture content, and about 2, $48.13 \mathrm{~g} / \mathrm{c} \mathrm{m}^{3}$ and $78.47 \mathrm{~g}$ for hasting emergence rice seeds at $35.2 \%$ seed moisture content, respectively. While the mass of 1000 seeds of egyptian hybrid rice No.1 were $22,89 \mathrm{~g}$ according to Abo-Yousef et. al (2011).

Mechanical rice planting is very important in saving hand labor, improving production, allowing further mechanization and decreasing production costs. Khan and El-Sahrigi (1990) showed that Egypt still need to develop simple row seeders for direct seeding for paddy under wet and dry field conditions. Younis et al. (1991) concluded that the mechanical drilling rice stayed only 124 days (less than the transplanted rice, which stayed about 134 days). Energy requirement for mechanical drilling was about (3.773 
$\mathrm{MJ}$ /ton), which is less than that required for manual and mechanical transplanting methods. Mechanical drilling recorded the minimum total cost (65 LE/ton) and the maximum net profit (135 LE/ton). So they consider the mechanical drilling method is the appropriate method for rice production in Egypt. Abo-Habaga (1994) reported that the bandwidth sowing method may be considered as the most suitable direct seeding methods for rice. It increased the efficiency of seed distribution regularity about $20.8 \%$ and crop yield about $14.39 \%$ in comparison with the hand sowing method.

Due to the lack of studies about the physical and engineering properties for Egyptian hybrid rice No.1, therefore, the present study was performed to determined some of physical and engineering properties for Egyptian hybrid rice No.1 to help in the development of a suitable precision vacuum planter for sowing dry, soaking and incubated rice seeds.

\section{MATERIALS AND METHODS}

The experiment was carried out on the Rice Mechanization Center (Agric. Eng. Res. Institute, Ministry of Agric.) at Kafr El-Sheikh to developed the Soffgia precision vacuum planter for sowing dry, soaked and incubated rice seeds.

\section{Soffgia precision vacuum planter}

Precision vacuum planter model (Soffgia ) Number G299 (fig. 1) used in planting the large grain (such as corn, soybeans, cotton, etc.) where the minimum distance between two rows $40 \mathrm{~cm}$ and a maximum distance of $70 \mathrm{~cm}$, and it didn't used to planting the small grains (such as wheat, rice, etc.). The technical specifications of the Soffgia Precision vacuum planter are summarized in table (1) .

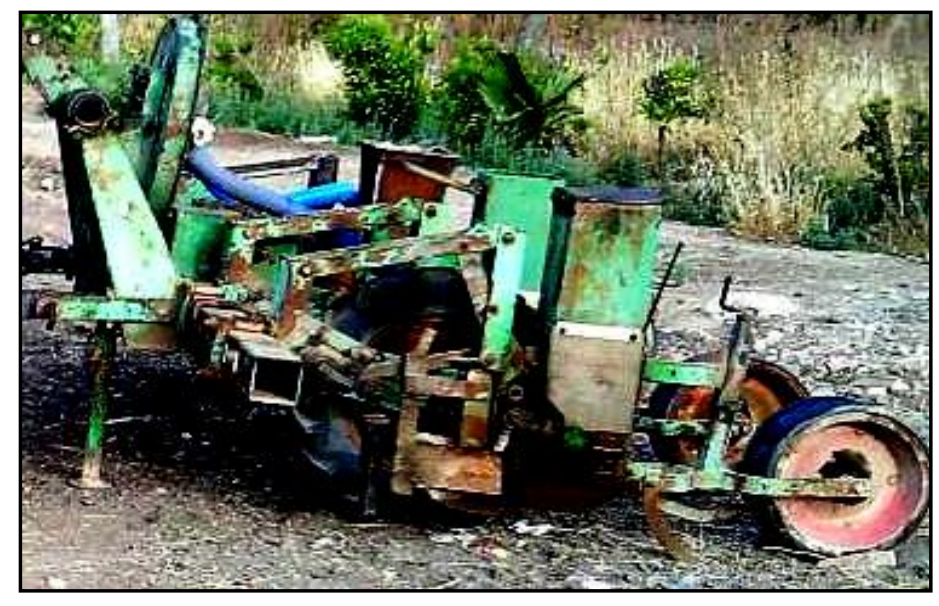

Fig. 1: Soffgia precision vacuum planter 
J. Soil Sci. and Agric. Eng., Mansoura Univ., Vol. 5 (5), May, 2014

Table 1: The technical specifications of Soffgia precision vacuum planter

\begin{tabular}{|l|c|}
\hline Specifications & Characteristic \\
\hline Model & Soffgia \\
\hline Country of production & Italy \\
\hline Planter type & Pneumatic \\
\hline Pneumatic type & Vacuum \\
\hline No. of planting units & 4 \\
\hline Distance between two row & $40-70 \mathrm{~cm}$ \\
\hline Type of furrow opener & Runner \\
\hline Type of closing device & Rubber wheel \\
\hline
\end{tabular}

\section{Seed moisture content}

The rice seed moisture content was determined using Grain Moisture Tester Model Kett KM No. 148-C Japan accuracy of 0.5\%. Three croup samples were taken to determine the seed moisture content for hybrid rice No1. at dry, soaking and incubated.

Mass of 1000 seeds

In order to determine the mean mass of 1000 seeds from (dry, soaked and incubated) rice seeds, samples of 1000 seeds were randomly selected. Each sample was weighted using an electronic balance with an accuracy of $0.01 \mathrm{~g}$.

\section{Shape index}

A random sample of one hundred grains was taken in the same time of determining the seed moisture content. The shape of each seeds sample was studied in terms of length (L), width (W), and thickness (T) by using a digital caliper with a sensitivity of $0.01 \mathrm{~mm}$. The obtained data were used to calculate the shape index of each sample, according to Ismail (1988).

Shape index $(\mathrm{SI})=\frac{L}{\sqrt{W . T}}$

At $(\mathrm{SI})>1.5$ the seed is considered oval and $(\mathrm{SI})<1.5$ the seed is considered spherical.

\section{Geometric, arithmetic mean diameter and seed surface area}

The geometric, arithmetic mean diameter and seed surface area of hybrid rice seeds are determined from the samples taken in the same time of determining the seed moisture content using the following equations according to Mohsenin, (1986):

$D_{g}=(L W T)^{1 / 3}$

$D_{a}=\frac{L+W+T}{3}$

$A_{s}=2 n(L . W)$

Where:

$D_{g}=$ Geometric mean diameter $(\mathrm{mm})$,

$\mathrm{D}_{\mathrm{a}}=$ Arithmetic mean diameter $(\mathrm{mm})$,

$A_{s}=$ Seed surface area $\left(\mathrm{mm}^{2}\right)$,

$\mathrm{W}=$ Width of seed $(\mathrm{mm})$, and

$L=$ Length of seed $(\mathrm{mm})$,

$\mathrm{T}=$ Thickness of seed $(\mathrm{mm})$. 


\section{Seed density}

The seed density was determined using the liquid displacement method (Mohsenin, 1986) by immersing a certain mass of seed in a certain benzene alcohol solution. The increase in the cylinder volume gave the absolute volume of rice seed. Ten samples were taken to determine the seed density. The density of rice seeds was determined by using the following equation:

$\rho=\frac{M}{V}$

Where:

$\rho=$ seed density $\left(\mathrm{g} / \mathrm{m}^{3}\right)$,

$M=$ mass of seeds $(\mathrm{g})$, and

$V=$ Volume of the seed $\left(\mathrm{m}^{3}\right)$.

The degree of sphericity

The degree of sphericity $(\phi)$ were determined from the samples of linear dimensions of hybrid rice seeds in the same time of determining the seed moisture content using the following equations according to Singh and Sarawat, (2005).

$\phi=\frac{(L W T)^{(1 / 3)}}{L} \times 100$

\section{coefficient of friction}

The dynamic coefficient of friction for hybrid rice grain on the surface of steel sheet iron was measured using an instrument constructed in the workshop of Rice Mechanization Center. The seeds sample was placed over the surface to be tested, which is titled around its side pivot. The friction angle was displayed when $75 \%$ of the seeds reached the spout and the tray was stopped friction coefficient for the mentioned sample was obtained as follows: $\mu=\tan \varphi$

Where:

$\mu=$ Friction coefficient, and

$\varphi=$ Friction angle $(\mathrm{deg})$.

\section{Repose angle}

Angle of natural slope (repose angle) of rice seeds was measured by an instrument every measurement was repeated 10 times and mean value was calculated to determine the angle of repose for each treatments.

\section{Terminal velocity of hybrid rice seeds}

Terminal velocity of hybrid rice seed was determined theoretically from the mass of hybrid rice seed, air density, projected area of hybrid rice seed and drag coefficient of semi-sphere shaped using the following equation according to Hexing, 1989.

$$
V_{t}=\sqrt{\frac{2 m g}{\rho_{a} A_{p} C_{d}}}
$$

Where:

$V_{t}=$ terminal velocity of hybrid rice seed $(\mathrm{m} / \mathrm{s})$,

$m=$ mass of particle hybrid rice seed $(\mathrm{kg})$,

$\rho_{a}=$ air density $\left(1.204 \mathrm{~kg} / \mathrm{m}^{3}\right)$, 
$A_{p}=$ projected area of hybrid rice seed $\left(\mathrm{m}^{2}\right)$, $C_{d}=$ drag coefficient (dimensionless).

\section{Seed indices}

Seed metering system uniformity was evaluated in terms of the miss index $\left(\mathrm{S}_{\mathrm{m}}\right)$,multiple index $\left(\mathrm{S}_{\mathrm{mu}}\right)$ and seed catch efficiency $\left(\eta_{c}\right)$ were calculated according to (Srivastava 1995).

\section{1-Seeds miss index $\left(S_{m}\right)$}

The seed miss index could be considered as the first indicator for the seed disposing performance. It was estimated for each treatment by counting the number of hole/sells that have no seeds and counting the number of the used holes/sells in each treatment. Then the percentage of miss index can be calculated as follows:

$$
\text { Sm\% }=\frac{B_{n}}{M} \times 100 \text {. }
$$

Where:

$\mathrm{Sm}=$ the percentage of seed miss index,\%,

$M=$ the total number of the used holes/sells.

$B_{n}=$ the number of holes that have no seeds.

\section{2- Seeds multiple index $\left(S_{\mathrm{mu}}\right)$}

The seed double ratio could be considered as the second indicator for the seed disposing performance. It was estimated for each treatment by counting the number of holes that have more than one seed and counting the number of the total holes in each treatment. Then the percentage of seeds multiples index can be calculated as follows:

$$
S_{m u} \%=\frac{A_{n}}{M} \times 100
$$

Where:

$$
\begin{gathered}
S_{m u} \%=\text { the percentage of seeds multiples index, \% } \\
A_{n}=\text { the number of holes that have more than one seeds. } \\
M=\text { the total number of the used holes/sells. }
\end{gathered}
$$

\section{3- The seed catch efficiency $\left(\eta_{c}\right)$}

The seed catching efficiency was estimated from the actual number of seeds which stuck to the holes of the seed plate to the total number of holes in the seed plate (theoretically). The actual number of seeds which stuck to the holes of the seed plate was donated by (ANC). However, the (TNS) is expressed of the theoretical number of seeds. The actual number of seeds that stuck to the seed plate was determined by collecting them in a plastic bag and counted them for each run under seven levels of blower speeds, for each seed plate and rice seed treatments. Then, the seed catching efficiency could be estimated as follows:

$$
\eta_{c}=\frac{A N C}{T N S} \times 100
$$

Where:

$\eta_{c}=$ the catching efficiency $(\%)$,

$T N S=$ the theoretical number of seed, and

$A N C=$ the actual number of seed. 


\section{Negative pressure and blower speed}

The negative pressure was measured by using vacuum gauge (Fig. 2) Model WIKA, overload limit $-1 \mathrm{~m}$ bar and staging (0-100 m bar) a sensitivity of ($0.01 \mathrm{~m}$ bar), under seven levels of blower speeds for each seed plate and rice seed treatments. The blower speeds was measured using a tachometer (Fig. 2 b) Model STICHT a sensitivity of $0.01 \mathrm{rpm}$.
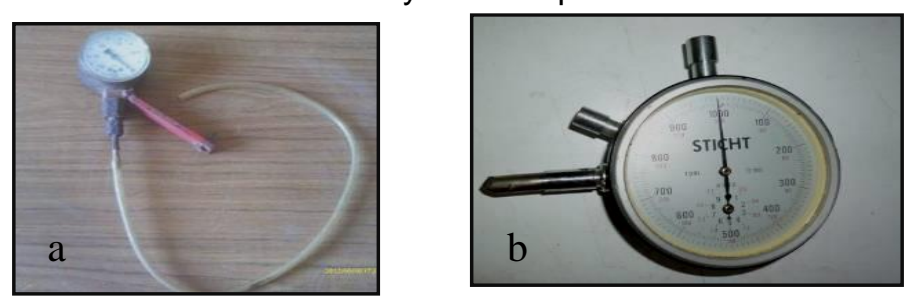

Fig. 2: Vacuum gauge and a tachometer

\section{RESULTS AND DISCUSSION}

\section{Seed moisture content}

Fig. (3) showed that the mean value of moisture content for dry seed was $14.9 \%$ with standard deviation about 0.62 . While the mean value of moisture content for soaked seed was $27.12 \%$ with standard deviation about 0.52 . Whereas the mean value of moisture content for incubated seed was $29.47 \%$ with standard deviation about 0.26 .

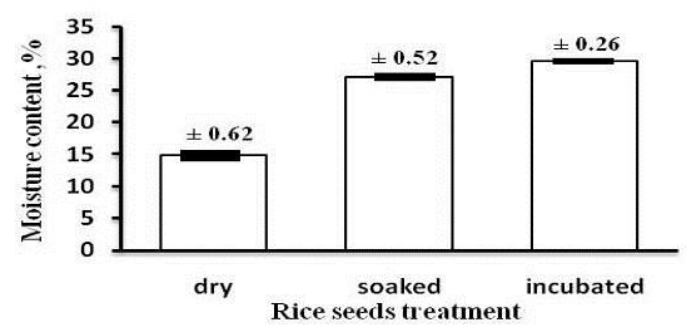

Fig. 3: Rice seed moisture content at different treatments

\section{Seed dimensions}

Results in fig. (4) showed that the average dimensions of dry rice seeds (length $7.75 \pm 0.31$, width $2.66 \pm 0.2$ and thickness $1.71 \pm 0.06 \mathrm{~mm}$ ), soaked rice seeds (length $8.18 \pm 0.26$, width $2.99 \pm 0.15$ and thickness $2.13 \pm 0.1$ $\mathrm{mm}$ ) and incubated rice seeds (length $8.26 \pm 0.28$, width $3.25 \pm 0.19$ and thickness $2.16 \pm 0.07 \mathrm{~mm}$ ). From previous results, it was clear that the shorter dimensions of the seeds were at dry seeds, the value was $(1.71 \pm 0.06 \mathrm{~mm})$ and so it was designed the hole diameter for seed plate less than $1.64 \mathrm{~mm}$. Therefore the suitable hole diameter was $1.5 \mathrm{~mm}$.

\section{Shape index:}

The results in fig (5) showed that the mean value of shape index for dry seed was 3.75 with standard deviation about 0.06 . While the mean value of shape index for soaked seed was 3.31 with standard deviation about 0.08 . 
Whereas the mean value of shape index for incubated seed was 3.10 with standard deviation about 0.06 . From above results, it can be recorded that increase the period of soaking seeds decrease the average shape index within the time period used in the study. From previous results, it was clear that all values of shape index higher than 1.5, this intend that all rice treatment take oval shape. This contributed us to fabricate precision vacuum planter seed holes as a cylindrical shape and to disqualify spherical from.

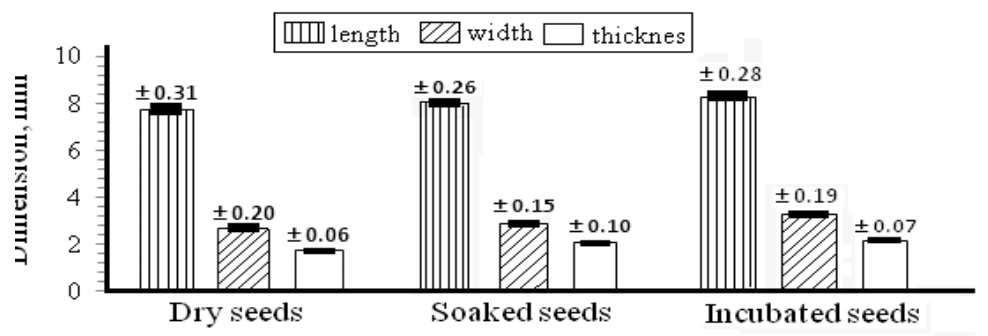

Rice seed treatments

Fig. 4: Dimensions of rice seed at different treatments

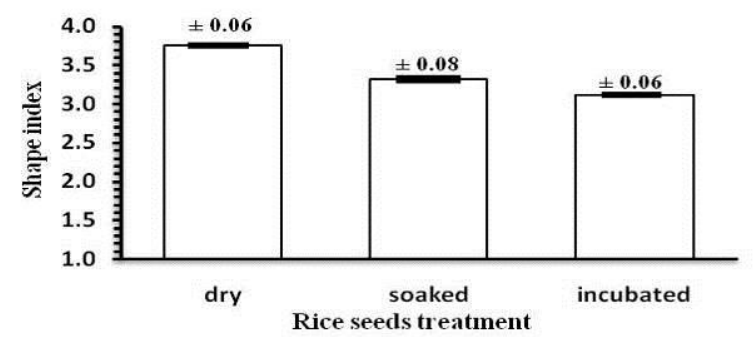

Fig. 5: Shape index of rice seed at different treatments

\section{Mass of 1000 seeds:}

Fig. (6) showed that the mean value of mass of 1000 rice seeds for dry seed was $22.20 \mathrm{~g}$ with standard deviation about 0.71 . While the mean value of mass of 1000 rice seeds for soaked seed was $28.54 \mathrm{~g}$ with standard deviation about 0.31 . Whereas the mean value of mass of 1000 rice seeds for incubated seed was 29.52 with standard deviation about 0.28. From above results, it can be recorded that increase the period of soaking seeds increase the average mass of 1000 rice seed within the time period used in the study. 


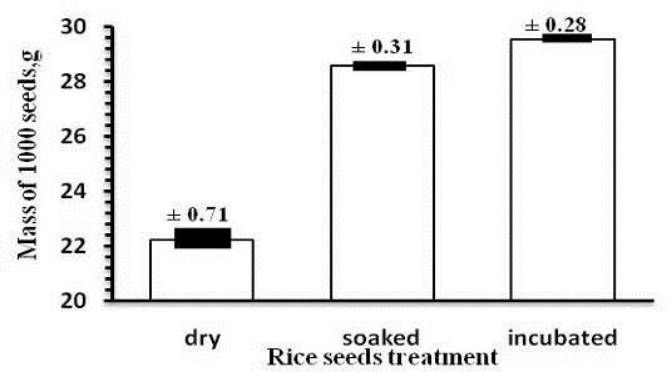

Fig. 6: Mass of 1000 rice seed at different treatments

\section{Seed density:}

The results in fig. (7) showed that the mean value of seed density for dry seed was $5.99 \mathrm{~g} / \mathrm{cm}^{3}$ with standard deviation about 0.11 . While the mean value of seed density for soaked seed was $7.33 \mathrm{~g} / \mathrm{cm}^{3}$ with standard deviation about 0.27 . Whereas the mean value of seed density for incubated seed was $8.26 \mathrm{~g} / \mathrm{cm}^{3}$ with standard deviation about 0.21 . From above results, it can be recorded that increase the period of soaking seeds increase the average seed density of rice seed within the time period used in the study.

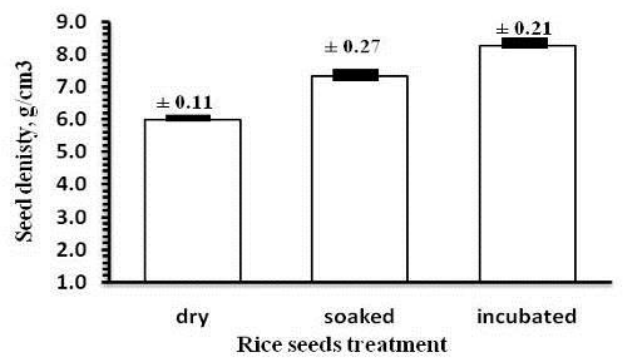

Fig. 7: Seed density of rice seed at different treatments

\section{Geometric and Arithmetic mean diameter}

The results in fig (8) showed that the mean value of geometric mean diameter for dry seed was $3.25 \mathrm{~mm}$ with standard deviation about 0.21 . While the mean value of geometric mean diameter for soaked seed was $3.73 \mathrm{~mm}$ with standard deviation about 0.26 . Whereas the mean value of geometric mean diameter for incubated seed was 3.85 with standard deviation about 0.27 . From above results, it can be recorded that increase the period of soaking seeds increase the average geometric mean diameter of rice seed within the time period used in the study. Also, the results indicated that the mean value of arithmetic mean diameter for dry seed was $4.06 \mathrm{~mm}$ with standard deviation about 0.25 . While the mean value of arithmetic mean diameter for soaked seed was $4.39 \mathrm{~mm}$ with standard deviation about 0.25 . Whereas the mean value of arithmetic mean diameter for incubated seed was $4.54 \mathrm{~mm}$ with standard deviation about 0.25 . From above results, it can be recorded that increase the period of soaking seeds increase the average arithmetic mean diameter of rice seed within the time period used in the study. 


\section{Spheriity}

The results in fig. (9) showed that the mean value of spherical for dry seed was $0.42 \%$ with standard deviation about 0.008 . While the mean value of spherical for soaked seed was $0.46 \%$ with standard deviation about 0.011 . Whereas the mean value of spherical for incubated seed was $0.47 \%$ with standard deviation about 0.008 . From above results, it can be recorded that increase the period of soaking seeds increase the average spherical of rice seed within the time period used in the study.
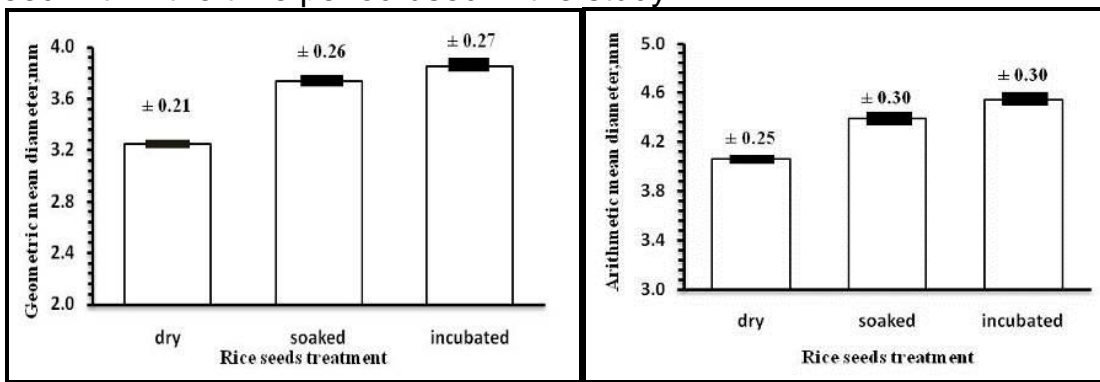

Fig. 8: Arithmetic and geometric mean diameter of rice seeds at different treatments

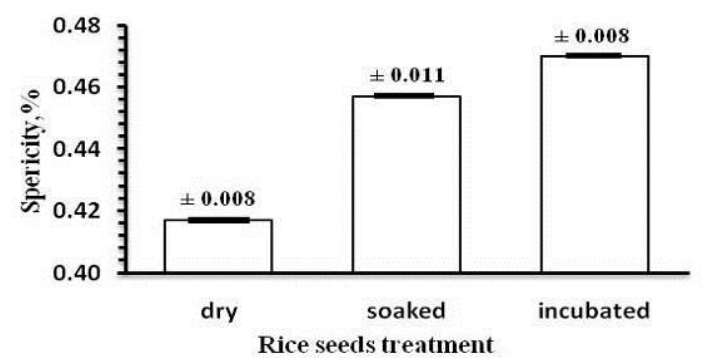

Fig. 9: Spheriity of rice seeds at different treatments

\section{Repose angle:}

The results in fig (10) showed that the mean value of repose angle for dry seed was $33.90^{\circ}$ with standard deviation about 1.13 . While the mean value of repose angle for soaked seed was $35.10^{\circ}$ with standard deviation about 0.91 . Whereas the mean value of repose angle for incubated seed was $38.60^{\circ}$ with standard deviation about 0.65 . From above results, it can be recorded that increase the period of soaking seeds increase the average repose angle of rice seed within the time period used in the study. From previous results, it was clear that the highest mean value of repose angle for the seeds were at incubated seeds, the value was $\left(38.60 \pm 0.65^{\circ}\right)$ and so it was designed the seed hopper in developed precision vacuum planter unit with slope higher than $38.60^{\circ}$. 


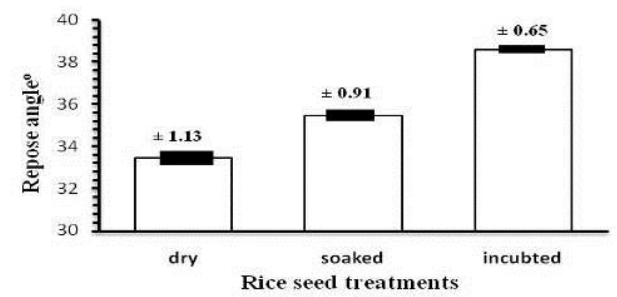

Fig. 10: Repose angle of rice seed at different treatments

\section{Coefficient of friction:}

The results in fig (11) showed that the mean value of dynamic coefficient of friction for dry seed was 0.73 with standard deviation about 0.011 . While the mean value of dynamic coefficient of friction for soaked seed was 0.75 with standard deviation about 0.008 . Whereas the mean value of dynamic coefficient of friction for incubated seed was 0.77 with standard deviation about 0.013 . From above results, it can be recorded that increase the period of soaking seeds increase the average dynamic coefficient of friction of rice seed within the time period used in the study.

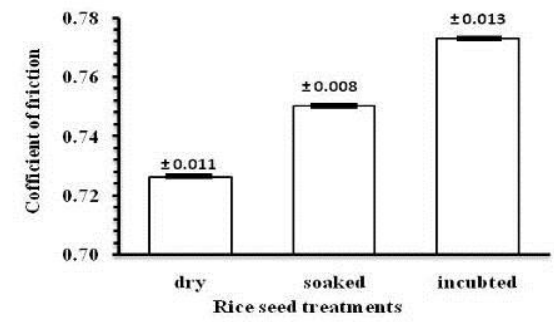

Fig. 11: Coefficient of friction of rice seed at different treatments

\section{Terminal velocity}

The results in fig (12) showed that the mean value of terminal velocity for dry seed was $6.68 \mathrm{~m} / \mathrm{s}$ with standard deviation about 0.67 . While the mean value of terminal velocity for soaked seed was $7.20 \mathrm{~m} / \mathrm{s}$ with standard deviation about 0.50 . Whereas the mean value of terminal velocity for incubated seed was 7.95 with standard deviation about 0.02 . From above results, it can be recorded that increase the period of soaking seeds increase the average terminal velocity of rice seed within the time period used in the study.

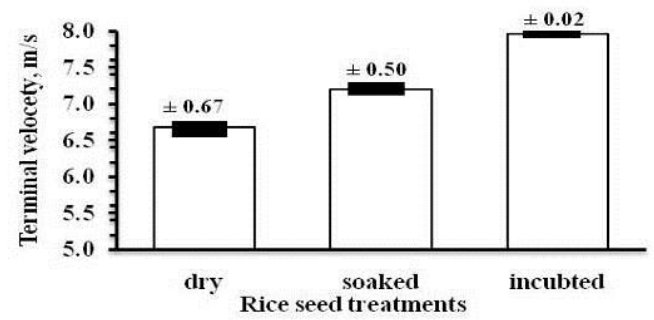

Fig. 12: Terminal velocity of rice seed at different treatments 


\section{Seeds miss index (\%)}

The results in fig.(13) showed that the effect of blower speeds on miss index for different type of seed plate at dry seeds, the highest value of miss index were $52.38,54.76$ and $57.14 \%$ at $2500 \mathrm{rpm}$ for all seed plates, while the lowest value were zero at $3800 \mathrm{rpm}$ for seed plate 1 and at 4300 rpm for seed plate 2 and 3 , respectively. Also, The results showed that the effect of blower speeds on miss index for different type of seed plates at soaked seeds, the highest value of miss index were $57.14,59.52$ and 60.32 $\%$ at $2500 \mathrm{rpm}$ for all seed plates, while the lowest value were zero at 3800 rpm for seed plate1, 2 and at $5000 \mathrm{rpm}$ for seed plate 3, respectively. Also, The results indicated that the effect of blower speeds on miss index for different type of seed plates at incubated seeds, the highest value of miss index were $61.10,64.29$ and $65.08 \%$ at $2500 \mathrm{rpm}$ for all seed, while the lowest value were zero at $3800 \mathrm{rpm}$ for seed plate 1 and 2 and at $4300 \mathrm{rpm}$ for seed plate 3 , respectively. From above results, it can be recorded that the most suitable blower speed were $3800 \mathrm{rpm}$ at seed plate 1 for all rice seed treatments (dry, soaked and incubated) and a suitable blower speed at seed plate 2 for soaked and incubated seeds, while the blower speed of $4300 \mathrm{rpm}$ was the most suitable speed of the seed plate 3 for dry and incubated seeds.

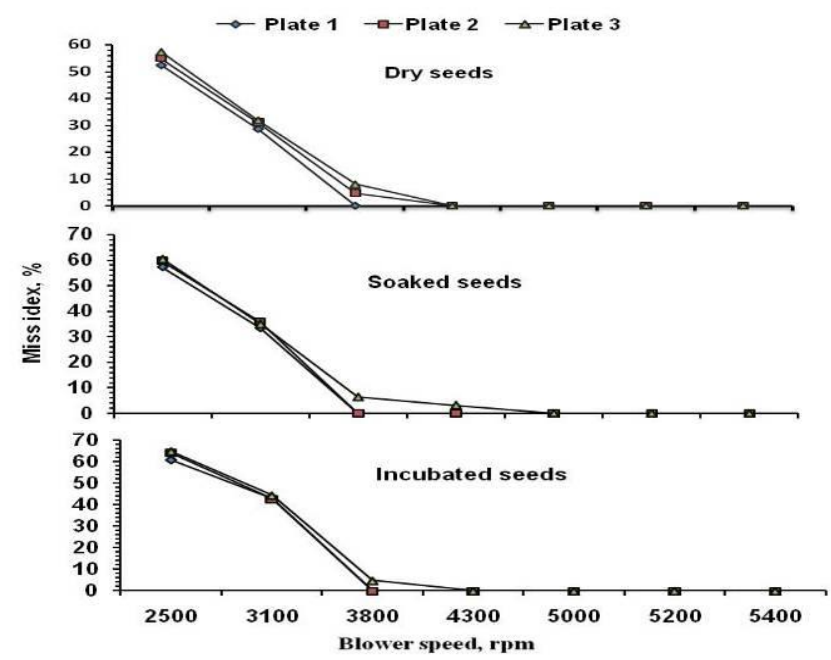

Fig. 13: Effect of blower speeds on miss index for different type of seed plate at different rice seed treatments

\section{The seeds multiple index (\%)}

The results in fig. (14) showed that the increase of blower speeds leads to increase of multiple index value. Results in fig. (14) showed that slow speeds 2500 and $3100 \mathrm{rpm}$ did not record any case of multiple index value for different type of seed plate at dry seeds. Increase the blower speed from 3100 to $3800 \mathrm{rpm}$ recorded increase of multiple index value from 0 to $3.17 \%$ for seed plate 3 , while the multiple index value increase into $9.52 \%$ for seed plate 1 and 2 . Also, the results showed that slow speeds 2500 and 3100 rpm did not recorded any case of multiple index value for different type of 
seed plate at soaked seeds. Increase the blower speed from 3100 to 3800 rpm recorded increase of multiple index value from 0 to $4.76 \%$ and $7.14 \%$ for seed plates 1 and 2 respectively, while plate 3 did not recorded any change of the multiple index value at this blower speed. Also, the results indicated that slow speeds 2500 and $3100 \mathrm{rpm}$ did not recorded any case of multiple index value for different type of seed plate at incubated seeds. Increase the blower speed from 3100 to $3800 \mathrm{rpm}$ recorded increase of multiple index value from 0 to $4.76 \%$ for seed plates 1 and 2 , while plate 3 did not recorded any change of the multiple index value at this blower speed. From above results, it can be recorded that the most suitable blower speed were 3100 rpm at all seed plates for all rice seed treatments (dry, soaked and incubated), while the blower speed of $3800 \mathrm{rpm}$ was the most suitable speed of the seed plate 3 for soaked and incubated seeds.

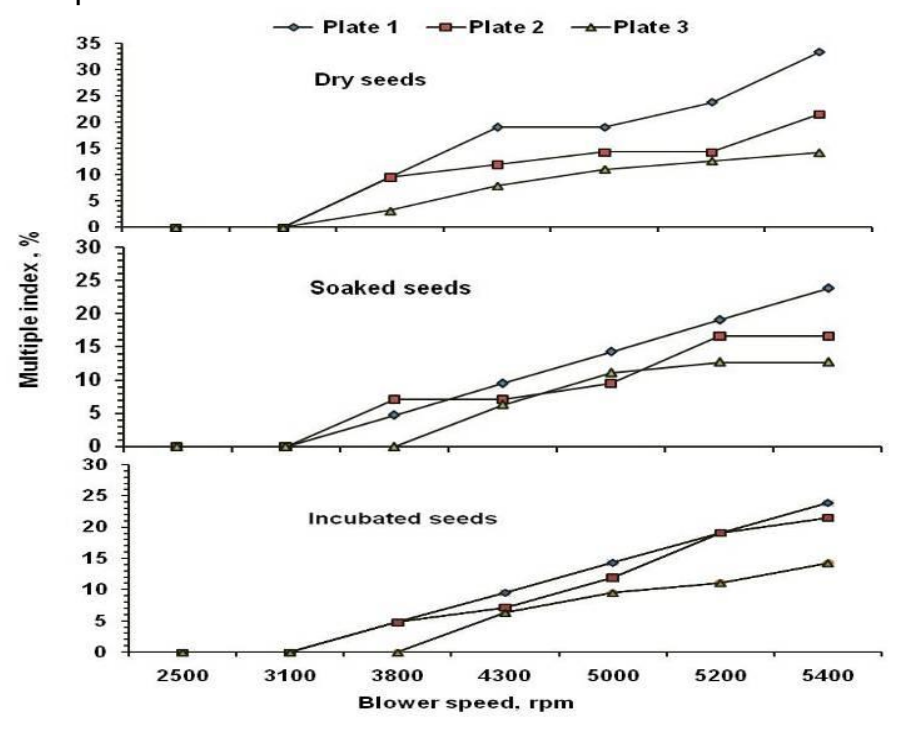

Fig. 14: Effect of blower speeds on multiple index for different type of seed plate at different rice seed treatments.

\section{The seed catch efficiency (\%)}

The results in fig. (15) showed that the effect of blower speeds on seed catch efficiency for different type of seed plate at dry seeds. Suitable blower speed, which is achieved the nearest value to the desired number of seeds for sowing was $3800 \mathrm{rpm}$ for seed plates 1 and 2, which achieved an increase of the number of seeds about 9.52 and $4.76 \%$ for seed number required for sowing. While the suitable blower speed for seed plate 3 was $4300 \mathrm{rpm}$, which recorded an increase about $7.94 \%$ for seed number required for sowing. Also, results in fig. (15) showed that the effect of blower speeds on seed catch efficiency for different type of seed plate at soaked seeds. Suitable blower speed, which is achieved the nearest value to the desired number of seeds for sowing was $3800 \mathrm{rpm}$ for seed plates 1 and 2, which achieved an increase of the number of seeds about 4.76 and $2.38 \%$ for 
seed number required for sowing. While the suitable blower speed for seed plate 3 was $4300 \mathrm{rpm}$, which recorded an increase about $6.34 \%$ for seed number required for sowing. Also, results in fig. (15) indicated that the effect of blower speeds on seed catch efficiency for different type of seed plates at incubated seeds. Suitable blower speed, which is achieved the nearest value to the desired number of seeds sowing was $3800 \mathrm{rpm}$ for seed plates 1 and 2 , that achieved an increase of the number of seeds about 4.76 and $0.00 \%$ for seed number required for sowing. While the suitable blower speed for seed plate 3 was $4300 \mathrm{rpm}$, which recorded an increase about $6.35 \%$ for seed number required for sowing. From above results, it can be recorded that the most suitable blower speed was $4300 \mathrm{rpm}$ for seed plate 3 , while the blower speed of $3800 \mathrm{rpm}$ was the most suitable speed for seed plates 1 and 2 for all rice seed treatments.

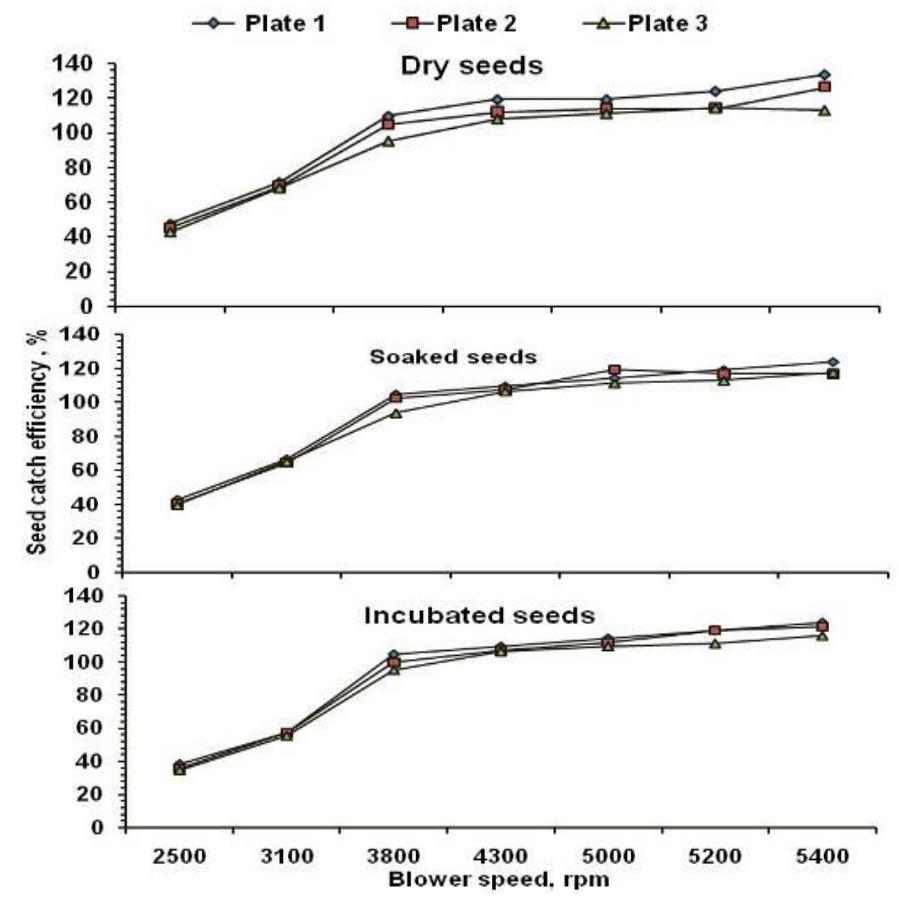

Fig. 15: Effect of blower speeds on seed catch efficiency for different type of seed plate at different rice seed treatments.

\section{Negative pressure and blower speeds}

Data in table (2) showed that the negative pressure at different level of blower speeds. The results showed that the highest value of seed catch efficiency were at negative pressure - $40 \mathrm{~m}$ bar, which obtained at blower speed $3800 \mathrm{rpm}$. when using seed plates 1 and 2 at all rice seed treatments, whereas the highest value of seed catch efficiency when used seed plate 3 which obtained at blower speed $4300 \mathrm{rpm}$ for all rice seed treatments. 
Table 2: Negative pressure at different level of blower speeds.

\begin{tabular}{|l|c|c|c|}
\hline $\begin{array}{l}\text { Blower speed, } \\
\text { rpm }\end{array}$ & $\begin{array}{c}\text { Blower speed, } \\
\mathbf{m} / \mathbf{s}\end{array}$ & $\begin{array}{c}\text { Negative pressure, } \\
\text { - } \mathbf{m} \text { bar }\end{array}$ & $\begin{array}{c}\text { Negative pressure, } \\
\mathbf{~} \mathbf{~ p a}\end{array}$ \\
\hline 2500 & 6.26 & 20 & 2 \\
\hline 3100 & 7.75 & 30 & 3 \\
\hline 3800 & 9.49 & 40 & 4 \\
\hline 4300 & 10.74 & 45 & 4.5 \\
\hline 5000 & 12.49 & 50 & 5 \\
\hline 5200 & 13.00 & 55 & 5.5 \\
\hline 5400 & 13.50 & 62.5 & 6.25 \\
\hline
\end{tabular}

Previous results lead to determine developed factors for soffgia precision vacuum planter to become suitable for small seeds sowing. The planter has been developed and manufactured from local raw materials at private workshop and can description as follows:

\section{Developed precision vacuum planter unit}

The precision vacuum planter unit under this study was developed for planting two rows with $150 \mathrm{~mm}$ apart instead of one row with other planters in the market and sowing dry, soaked and incubated hybrid rice seeds. A precision vacuum planter development unit was designed, fabricated and assembled to meet the stated requirements under this study (Fig.16 and 17). The experimental developed precision vacuum planter unit was fabricated using local materials.

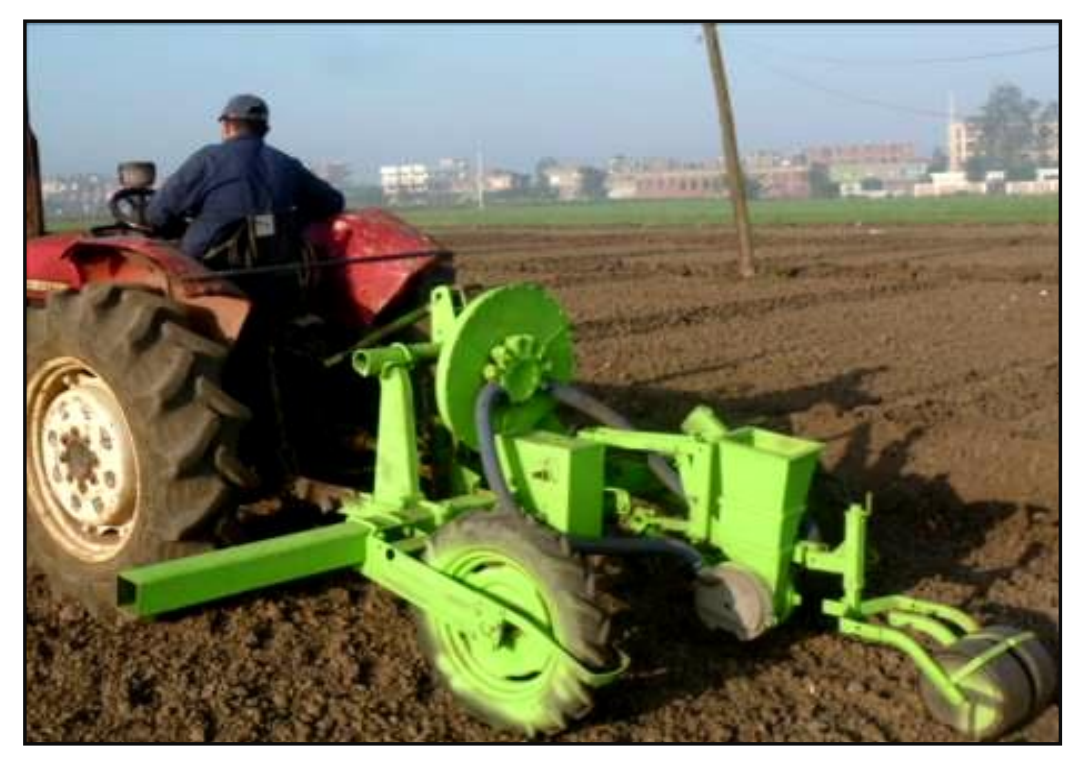

Fig. 16: Developed precision vacuum planter unit 


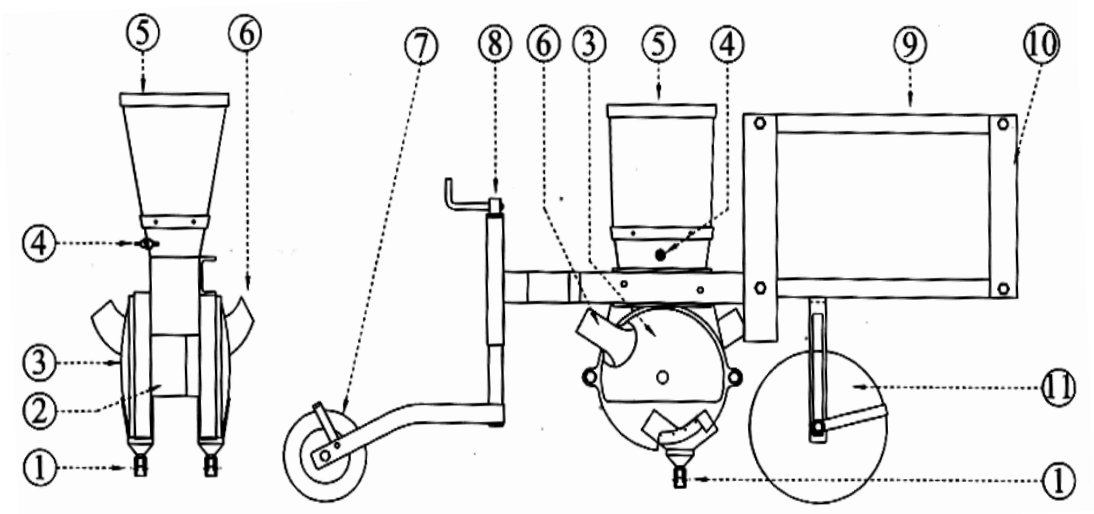

1- Seed counter. 2- Gearbox for two rows.
3- Chamber of seed suction. 4- Level seed control.
5- Seed box 6- Suction air pipe. 7- Rear wheel.
8- Crank to adjusting planting depth. 9- Frame.
10- Hitch point. 11- Furrow opener.

Fig. 17: Schematic diagram of developed precision vacuum planter components:

The developed precision vacuum planter consists of the following 1- Seed box and seed chamber

The seed box was fabricated from steel sheet iron with $3 \mathrm{~mm}$ thickness. The seed box consists of two parts. The upper part in the form of a cube dimensions $20 \times 20 \times 18 \mathrm{~cm}$ and the bottom part in the form pyramidshaped minus, its base upper $20 \times 20 \mathrm{~cm}$ and the base bottom $18 \times 16 \mathrm{~cm}$ and the height of $4.8 \mathrm{~cm}$. Seed box was designed to use several types of rice seeds with different repose angles ranged from $33.44^{\circ}$ to $38.60^{\circ}$ for dry and incubated rice seed, respectively. The seed chamber was developed to give two row feed in the planting unit, the distance between them about $150 \mathrm{~mm}$.

2- Seed metering system

Seed metering mechanism under this study was developed for planting two rows with $150 \mathrm{~mm}$ apart. The seed metering mechanism consisted of the following parts:

a-Vertical seed plate: Three different types of seed plate designed of stainless steel material, thickness of $3 \mathrm{~mm}$ and a diameter of $220 \mathrm{~mm}$. Each plate has some of holes (26, 52 and 78 holes) with $1.5 \mathrm{~mm}$ diameter.

b- Plate of vacuum flow: The plate of vacuum flow was fabricated from sort of plastics called (Teflon) with outer diameter $240 \mathrm{~mm}$, it designed with a cavity diameter and thickness of new seed plate $(220$ and $3 \mathrm{~mm}$ ) inside plate of vacuum flow to best control of suction air and as well as to reduce the friction between the seed plate and plate of vacuum. 
c- Transmission system: Transmission system has two functions for driving metric device from land wheel and for changing the auger shaft rotating speed to obtain different application seed rates, $\mathrm{kg} / \mathrm{feddan}$.

\section{3-Furrow opener}

A single disc-type opener with two outlets was used. The distance between two openers $150 \mathrm{~mm}$, The dimensions of furrow opener are $3 \mathrm{~mm}$ thickness and $250 \mathrm{~mm}$ diameter.

\section{4-Covering seeds system}

Two press wheels were used to cover the seeds in two rows. A pair of closing press wheels closes the furrow for proper seed-soil contact. Adjustable a turn buckle joint applied different force levels to the closing press wheel to achieve the desired compaction level. The dimensions of a press wheel cover are $120 \mathrm{~mm}$ thickness and $200 \mathrm{~mm}$ diameter and the distance between two wheel $50 \mathrm{~mm}$.

\section{5- Level seed control and Seed counter}

The level seed control and seed counter are electronic circuit to indicate the level of seeds in the seed box and number of sown seeds, they designed in the workshop of rice mechanization center (Agric. Eng. Res. Institute, Ministry of Agric.) in Kafr El-Sheikh government.

\section{REFERENCE}

Abo-Habaga, M. (1994) A suitable method for direct sowing rice in Egypt". Misr J. Ag. Eng., Vol.11, No.2: 302-311.

Abo-Youssef, M.I.; Sorour, S.Gh.; Abdelkrem, M.Z. and M.A. Tawfik (2011) The effect of sowing date on the productivity of some rice varieties. J. Agric. Res. Kafer El-Sheikh Univ., 37 (2): 317-330.

Bulletin of the Ministry of Agriculture, Agricultural Economy in, 2012 in Arabic.

Hexing, H.U., (1989) Effect of design parameters on cleaning performance in an oscillating screen- blower cleaning unit. Master of Science Thesis, Faculty Grad. Sch., Univ. Philippines Los Banos, Philippines: 63-66.

Ibrahim, M.M.; Abd El-Mageed, H.N. and T.H. Abd-Alla (2008) Evaluation the field performance of a developed planting machine sutable for soaked rice". Misr J. Ag. Eng., 25(3): 677-692

Ismail, Z. E. and E. H. El-Hanify (2009) Construction and testing the seedpunch planter. Misr J. Ag. Eng., 26(1): 597-607

Ismail, Z.E., 1988: "Some of the phsio-mechanical properties for potato tubers". J. Agric. Sci. Mansoura Univ. 13 B (4): 2259 - 2270.

Khan, A.U. and A.F. El-Sahrigi (1990) Selective mechanization of rice farming system in tropical Asia. Agric. Eng. Today 14(3,4): 4052.

Mohsenin, N.N., 1986: "Physical properties of plant and animal materials". Gordon and Breach Science Pub., N.Y.: 103-105.

Singh, R. C and D. C. Saraswat, (2005) Optimization of design and operational parameters of a pneumatic seed metering deice for planting cottonseeds. Bio-systems Engineering, 92(4): 429-433. 
Srivastava, A. E. (1995) Engineering principals of agricultural machines. ASAE textbook Number 6. Published by the American Society of Agricultural Engineers. Pamela De Vore-Hansen, Editor Books\& Journals, June 1995.

Younis, S.M.; M.A. Shaiboon and A.O. Aref (1991) Evaluation of some mechanization methods of rice production in Egypt. Misr. J. Ag. Eng. 8(1): 39-49.

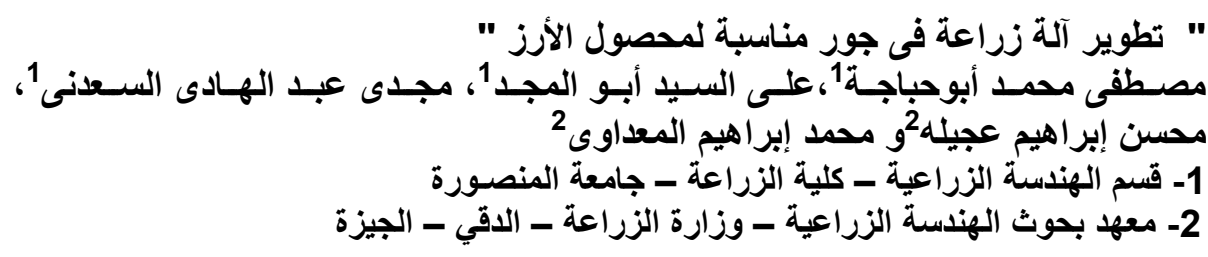

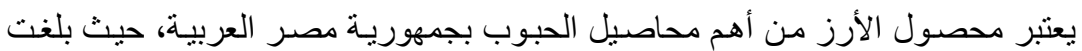

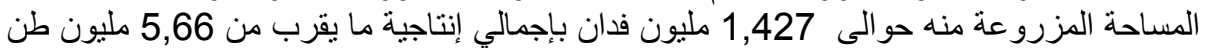

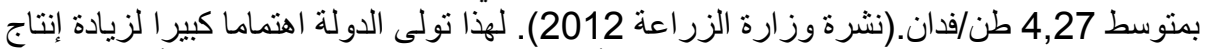

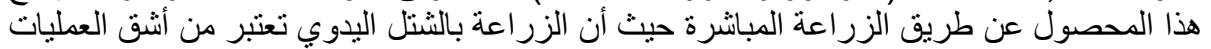

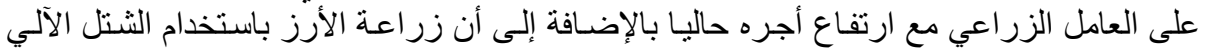

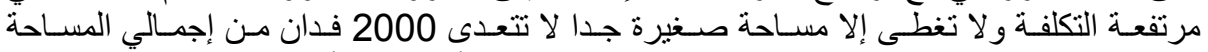

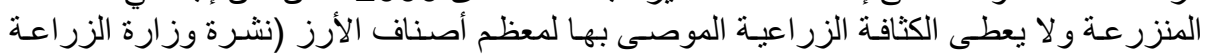

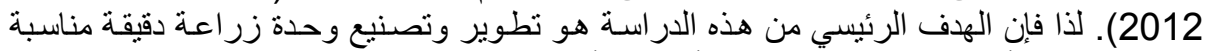

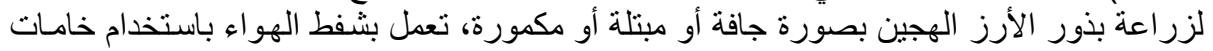

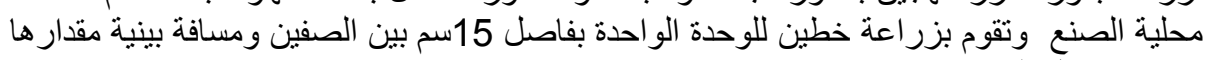
15 سم داخل الصف.

أجريت تجارب معملية بغرض در اسـة مجمو عـة من الخو اص الطبيعية و الهندسية لبذور

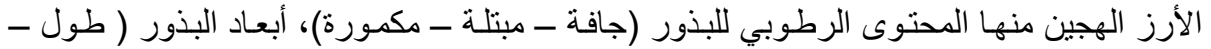

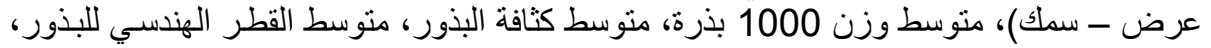

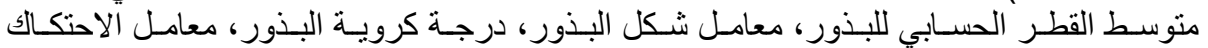

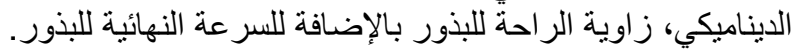

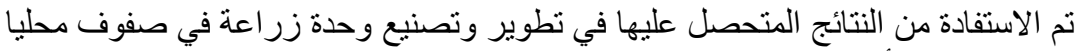

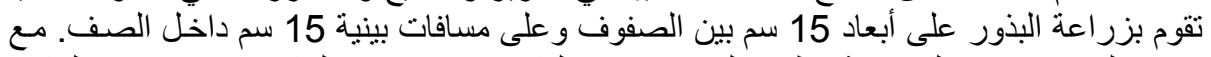

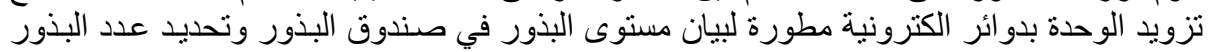

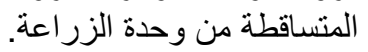

